\title{
Hydrogeochemistry and groundwater quality appraisal of part of south Chennai coastal aquifers, Tamil Nadu, India using WQI and fuzzy logic method
}

\author{
S. Krishna Kumar • R. Bharani • N. S. Magesh • \\ Prince S. Godson • N. Chandrasekar
}

Received: 4 July 2013 / Accepted: 17 December 2013/Published online: 4 January 2014

(C) The Author(s) 2014. This article is published with open access at Springerlink.com

\begin{abstract}
The present study was carried out to evaluate the groundwater quality and its suitability for drinking purposes in the urban coastal aquifers of part of south Chennai, Tamil Nadu, India. Twenty-three groundwater samples were collected during March 2012. The minimum and maximum values of $\mathrm{pH}$ (6.3-8 on scale), electrical conductivity $(620-12,150 \mu \mathrm{S} / \mathrm{cm})$, total dissolved solids (399.28-7,824.6 mg/l), carbonate $(0-30 \mathrm{mg} / \mathrm{l})$, bicarbonate $(0.9-58.9 \mathrm{mg} / \mathrm{l})$, chloride $(70.9-4,067.89 \mathrm{mg} / \mathrm{l})$, sulphate (17.4-105 mg/l), nitrate $(0.4-6.0 \mathrm{mg} / \mathrm{l})$, calcium $(30-200$ $\mathrm{mg} / \mathrm{l})$, magnesium (1.2-164 mg/l), sodium (69-1,490 mg/ 1) and potassium $(8-340 \mathrm{mg} / \mathrm{l})$ were recorded in the coastal aquifers of Chennai city. The groundwater samples show that the majority of the sampling points clustered on the $\mathrm{NaCl}$ and mixed $\mathrm{CaMgCl}$ facies of the piper trilinear diagram. In the Gibbs diagram, the majority of the sampling points fall under rock water and evaporation dominance
\end{abstract}

S. Krishna Kumar $(\bowtie)$

Department of Civil Engineering, St, Peters University, Avadi, Chennai 600054, Tamil Nadu, India

e-mail: coralkrishna@yahoo.co.in

\section{R. Bharani}

Department of Electrical and Electronics Engineering, Prathyusha Institute of Technology and Management, Chennai 602025, Tamil Nadu, India

e-mail: bharanikrishnakumar@gmail.com

N. S. Magesh · P. S. Godson · N. Chandrasekar Centre for GeoTechnology, Manonmaniam Sundaranar University, Tirunelveli 627 012, Tamil Nadu, India e-mail: mageshissivan@gmail.com

P. S. Godson

e-mail: Princegodsons@gmail.com

N. Chandrasekar

e-mail: profncsekar@gmail.com field. Fuzzy membership classification suggests that the majority of the samples fall under good water type followed by excellent water and poor water categories. Groundwater quality index showing the majority of the samples falls under excellent to poor category of water. A positive correlation was observed with $\mathrm{Cl}^{-}, \mathrm{SO}_{4}{ }^{2-}, \mathrm{Ca}^{2+}$, $\mathrm{Na}^{+}, \mathrm{K}^{+}, \mathrm{EC}$ and TDS. The extracted results of the correlation matrix and geochemical analysis suggest that the dominant ions of groundwater $\left(\mathrm{Na}^{+}, \mathrm{Ca}^{2+}, \mathrm{K}^{+}, \mathrm{Cl}^{-}\right.$and $\mathrm{SO}_{4}{ }^{2-}$ ) were derived from seawater intrusion and gypsum dissolution process. Nitrate concentration is most significantly derived from anthropogenic sources.

Keywords Groundwater quality assessment . Geochemistry · Coastal aquifers · Chennai City

\section{Introduction}

Groundwater is the major source of water supply for drinking and domestic purposes in urban as well as rural parts. Groundwater contamination is one of the most important environmental issues in the recent world (Vodela et al. 1997). Groundwater quality depends on the quality of recharged water, atmospheric precipitation, inland surface water and on subsurface geochemical processes. Temporal changes in the origin and constitution of the recharged water, hydrologic and human factors may cause periodic changes in groundwater quality. The concentrations of naturally occurring chemicals such as chloride, iron, manganese, sodium, etc. does not alter public health at certain levels, but may affect the acceptability of drinking water. Chemical reactions such as weathering, dissolution, precipitation and other related processes commonly take place below the surface. The quality of groundwater at any 
point below the earth's surface reflects the combined effects of many processes along the groundwater flow path. Geochemical processes are responsible for the seasonal and spatial variation in groundwater chemistry. In addition, the poor quality of water may lead to leaching of nutrient and release of metals from soil. The determination of groundwater quality is important to observe the suitability of water for a particular use. Geochemical studies of groundwater provide a better understanding of possible changes in quality as development progresses. The migration of contaminants and the controlling procedures of water quality are effective if the natural baseline quality is determined with an acceptable degree of confidence. Anthropogenic activities can alter the relative contributions of the natural causes of variations and also introduce the effects of pollution (Whittemore et al. 1989; Sarath Prasanth et al. 2012). Groundwater contamination in an urban environment is a major issue especially in coastal urban areas (Ballukraya and Ravi 1998; Venugopal et al. 2009; Arunprakash et al. 2013) Various statistical analyses including multivariate analysis and principal component analysis are used to interpret the hydrogeological and suitability of groundwater (Vasanthavigar et al. 2010; Krishnakumar et al. 2011; Magesh et al. 2012). The present study was carried out to assess the groundwater quality and its suitability for drinking purposes in a part of south Chennai coastal aquifers, Tamil Nadu, India.

\section{Study area}

Chennai is the capital of Tamil Nadu State and is located on the Coromandel Coast of the Bay of Bengal between $13.04^{\circ} \mathrm{N}$ and longitude $80.17^{\circ} \mathrm{E}$ (Fig. 1). The city covers an area of $174 \mathrm{~km}^{2}$. The rainfall in the study area is chiefly controlled by the northeastern monsoon (October, November and December) with an average annual rainfall of $1,200 \mathrm{~mm}$. The study area enjoys a tropical climate with a mean annual temperature and humidity of $24.3-32.9{ }^{\circ} \mathrm{C}$ and $65-84 \%$, respectively. The humidity is usually in the
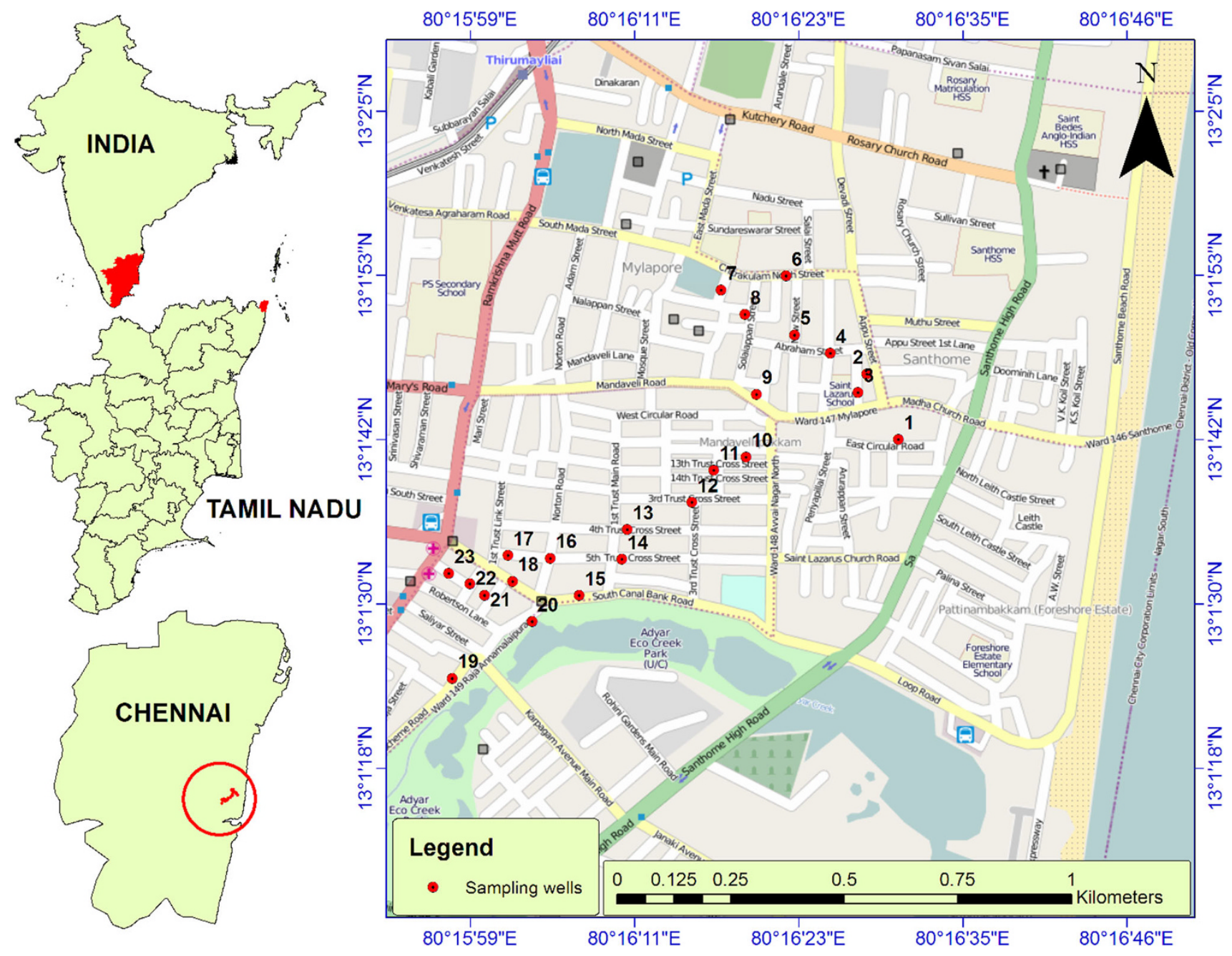

Fig. 1 Groundwater sample location map of the study area 
range of $65-84 \%$. A major part of the study area has flat topography with very gentle slope towards east. The coastal aquifers are underlain by various geological formations from ancient Archaean to Recent alluvium. The alluvium covers the major part of the study area, which consists of sand, silts and clays. The thickness of alluvium varies from place to place to a maximum of $28 \mathrm{~m}$.

\section{Methodology}

Sample collection and geochemical analysis

The fieldwork was carried out during the pre-monsoon period to collect the groundwater samples from bore wells. Groundwater samples were obtained from 23 wells and their depths ranged from 80 to $150 \mathrm{~m}$ bgl. The groundwater samples were collected in high density polyethylene bottles prewashed with $1 \mathrm{~N}$ hydrochloric acid followed by distilled water and then rinsed two to three times before sampling using sampling water. Water samples were collected from borewells at least after $10 \mathrm{~min}$ of pumping. The collected samples were transferred to a laboratory for further analysis and kept at $5{ }^{\circ} \mathrm{C}$. The samples were filtered using $0.45 \mu \mathrm{m}$ cellulose membrane before the analysis. Groundwater samples for cation analysis were acidified with ultrapure hydrochloric acid in the laboratory. The temperature of the groundwater samples was determined using a common mercury thermometer. Field measurements of $\mathrm{pH}$ and EC were made using a handheld multi water quality probe (HANNA HI-9828, USA). Electrode calibration was made using a standard solution of HI 9828 (HANNA-Calibration solution). Carbonate and bicarbonate analysis was carried out using acid titration $(1 \mathrm{~N}$ diluted sulphuric acid) method; Chloride concentration was measured by $\mathrm{AgNO}_{3}$ titration method and sulphate was determined by $\mathrm{BaCl}$ (turbidity techniques) method using a spectrophotometer. Sodium and potassium were analysed using flame photometer, and calcium and magnesium by volumetric method. The analytical procedures are as suggested by the American Public Health Association (APHA 1995). The analytical precision and measurement reproducibility was $<2 \%$. The ionic balance error for studying ions was within $\pm 5 \%$. The base map of the study area was prepared using the Survey of India topographic sheets $(66 \mathrm{C} / 4$ and $66 \mathrm{C} / 8)$ and digitized using Arc GIS 9.3 software. Trimble ${ }^{\circledR}$ Recon GPS was used to find the location of each sampling site and the coordinates were imported to GIS platform for preparation of the base map. The geochemical results are plotted on the piper trilinear plot using AquaChem 4.0 software, and Gibbs diagram is plotted to assess the quality-controlling mechanism and dominant hydro-geochemical facies of the study area.
Water quality index calculation

The water quality index (WQI) was calculated for evaluating the influence of natural and anthropogenic activities based on several key parameters on groundwater chemistry. To calculate the WQI, the weight was assigned to the physicochemical parameters according to the parameters' relative importance in the overall quality of water for drinking water purposes. The assigned weight ranges from 1 to 5 . The maximum weight of 5 was assigned to parameters such as nitrate and total dissolved solids, and weight 1 to magnesium. The relative weight is computed from the following equation:

$W_{i}=w_{i} / \sum_{i=1}^{n} w_{i}$

where $W_{i}$ is the relative weight, $w_{i}$ is the weight of each parameter, and $n$ is the number of parameters.

The quality rating scale for each parameter is calculated by dividing its concentration in each water sample by its respective standards (World Health Organization 2011) and multiplying the results by 100 .

$q_{i}=\left(C_{i} / S_{i}\right) \times 100$

where $q_{i}$ is the quality rating, $C_{i}$ is the concentration of each chemical parameter in each sample in milligrams per litre, and $S_{i}$ is the World Health Organization standard for each chemical parameter in milligrams per litre according to the guidelines of the World Health Organization (2011).

For computing the final stage of WQI, SI is first determined for each parameter. The sum of SI values gives the water quality index for each sample.

$\mathrm{SI}_{i}=W_{i} \times q_{i}$

$\mathrm{WQI}=\sum \mathrm{SI}_{i}$

where $\mathrm{SI}_{i}$ is the sub-index of $i$ th parameter, $q_{i}$ is the rating based on concentration of $i$ th parameter and $n$ is the number of parameters.

Fuzzy membership calculation

The fuzzy membership function was used to assess water quality according to standard values. The linear membership functions are adopted to reduce the complexity of the model. This member function was suggested by Bing Zhang et al. (2012) and is expressed as

$$
r_{i j}=\left\{\begin{array}{c}
0,\left(C_{i} \leq S_{i j}-1 \text { or } C_{i} \geq S_{i j}-1\right) \\
\frac{C_{i}-S_{i j}-1}{S_{i j}-S_{i j}-1}\left(S_{i j}-1<C_{i}<S_{i j}\right) \\
\frac{S_{i j}+1-C_{i}}{S_{i j}+1-S_{i j}}\left(S_{i j}<C_{i}<S_{i j}+1\right) \\
1,\left(C_{i}=S_{i}\right)
\end{array}\right.
$$

where $r_{i j}$ denotes the fuzzy membership of indicator $i$, to class $j, C_{j}$ is analytical value of water quality indicator $i$ and 
$S_{i j}$ is the allowable water quality indicator. The fuzzy membership matrix $R$ consists of water quality indicator and classes.

The weight $\left(W_{i}\right)$ of the water quality indicator is calculated from the following equation

$W_{i}=\frac{C_{i}}{S_{i}}$

where $W_{i}$ is the weight of the water quality index $i, C_{i}$ is the analytical value of the water quality indicator $i$ and $S_{i}$ is the arithmetic mean of allowable value of each class. The normalized weight of each indicator is calculated from the following equation

$a_{i}=\frac{C_{i}}{S_{i}} / \sum_{i=1}^{m} \frac{C_{i}}{S_{i}}=W_{i} / \sum_{i=1}^{m} W_{i}$

where, $a_{i}$ is the normalized weight of indicator $i$ and $\sum_{i=1}^{n} W_{i}$ is the summing up weight of all water quality parameters. The fuzzy $A$ consists of weight of each water quality indicator.

The water quality assessment by fuzzy logic membership is based on the matrix $B$ :

$B=A \cdot R$

The fuzzy $B$ is the matrix of the membership of each water quality class. The water sample is classified in the class with maximizing membership.

\section{Results and discussion}

Physico-chemical parameters

Maximum, minimum, mean and their standard deviation values of the analysed variables of groundwater samples
( $n=23)$ and drinking water standards (World Health Organization 2011; BIS 1991) are summarized in Table 1. Based on the land use classification, the coastal areas of the study area chiefly consist of urban and industrial areas. The important physico-chemical parameters are discussed below. The groundwater temperature ranges from 26 to $30{ }^{\circ} \mathrm{C}$. The $\mathrm{pH}$ value of most of the groundwater samples varies from 6.3 to 8.0 with an average value of 7.26 , which indicates that the groundwater is slightly acidic to alkaline in nature. The $\mathrm{pH}$ value of the groundwater shows moderate negative correlation coefficient with the majority of cations and anions. Therefore, it has no adverse effect on human health. The slightly acidic to basic nature of the groundwater is probably attributed to anthropogenic activities and seawater intrusion. Electrical conductivity (EC) is an indicator of the presence of ions and concentrations of dissolved components and has a direct relationship with salinity and TDS which are used for groundwater classification. The EC ranges from 620 to $12,150 \mu \mathrm{S} / \mathrm{cm}$. Groundwater was reclassified using a TDS (after Todd 1980) into very fresh $(0-250 \mathrm{mg} / \mathrm{l})$, fresh (250-1,000 mg/l), brackish (1,000-10,000 mg/l) and saline $(10,000-100,000 \mathrm{mg} / \mathrm{l})$. Using this categorization, therefore, only about $56.2 \%$ of groundwater samples qualifies as fresh, while over $43.5 \%$ fall within brackish water category, which indicates the degree of variation in water quality due to entering of foreign matter into the groundwater system.

The concentration of carbonate and bicarbonate varies from 0 to 30 and 0.9 to $58.9 \mathrm{mg} / \mathrm{l}$ with a mean average of 3.27 and $7.60 \mathrm{mg} / \mathrm{l}$, respectively. Bicarbonate is responsible for the alkalinity of groundwater. The carbonate and bicarbonates are probably derived from weathering of silicate rocks, dissolution of carbonate precipitates,

Table 1 Mean, minimum and maximum concentration $(n=23)$ of physico-chemical parameters, major ions, (World Health Organization, WHO 2011) and BIS (Bureau of Indian Standards 1991) standards of coastal aquifers of Chennai City, Tamil Nadu, India

\begin{tabular}{|c|c|c|c|c|c|c|}
\hline Parameters & Mean & Min & Max & SD & WHO standard & BIS standard \\
\hline Temp & 27.7 & 26 & 30 & 0.82 & - & - \\
\hline $\mathrm{pH}$ & 7.26 & 6.3 & 8 & 0.45 & $6.5-8.5$ & $6.5-8.5$ \\
\hline $\mathrm{EC}$ & $2,746.45$ & 620 & 12150 & $3,270.41$ & 500 & - \\
\hline TDS & $1,768.72$ & 399.28 & 7824.6 & $2,106.15$ & 500 & 500 \\
\hline $\mathrm{CO}_{3}$ & 3.27 & 0 & 30 & 7.86 & - & - \\
\hline $\mathrm{HCO}_{3}$ & 7.6 & 0.9 & 58.9 & 14.51 & 500 & - \\
\hline $\mathrm{Cl}$ & 700.94 & 70.9 & 4067.89 & $1,078.47$ & 250 & 250 \\
\hline $\mathrm{SO}_{4}$ & 58.67 & 17.4 & 105 & 29.83 & 250 & 200 \\
\hline $\mathrm{NO}_{3}$ & 3.87 & 0.4 & 6 & 2.26 & 45 & 45 \\
\hline $\mathrm{Ca}$ & 85.09 & 30 & 200 & 40.62 & 75 & 75 \\
\hline $\mathrm{Mg}$ & 37.04 & 1.2 & 164 & 45.86 & 50 & 30 \\
\hline $\mathrm{Na}$ & 329.05 & 69 & 1490 & 439.16 & 200 & - \\
\hline $\mathrm{K}$ & 91.82 & 8 & 340 & 82 & 12 & - \\
\hline
\end{tabular}

Temperature in degrees $\left({ }^{\circ} \mathrm{C}\right)$; $\mathrm{pH}$ on scale; EC in $\mu \mathrm{s} / \mathrm{cm}$; major ions and TDS in $\mathrm{mg} / \mathrm{l}$ 
atmospheric and soil $\mathrm{CO}_{2}$ gas (Jeong 2001; Krishnakumar et al. 2011). Chloride occurs naturally in all types of water. The amount of chloride content in the water samples was recorded from 70.9 to $4,067.89 \mathrm{mg} / \mathrm{l}$. Weathering and dissolution of salt deposits, seawater intrusion and irrigation return flow are commonly responsible for the increasing chloride content in the groundwater (Jeevanandam et al. 2012). According to Walker et al. (1991), $\mathrm{Cl}$ ion concentration in the groundwater normally arises from sources like paleoseawater entrapped sediments, solubility of Cl-bearing evaporation deposits and from anthropogenic sources. The high concentration of $\mathrm{Cl}$ is observed in the study area; this is a common phenomenon in the SE coast of Tamil Nadu (Chidambaram et al. 2007). The sulphate concentration ranges from 17.4 to $105 \mathrm{mg} / \mathrm{l}$, with a mean value of $58.67 \mathrm{mg} / \mathrm{l}$. The concentration of sulphate is within the maximum permissible limit of WHO standard (200 mg/l). The high concentration of sulphate may be attributed to contamination of untreated industrial and domestic waste and their effluents (Baruah et al. 2008; Jeevanandam et al. 2012). However, the concentration of sulphate is probably derived from the gypsum dissolution process. The concentration of nitrate does not exceed $10 \mathrm{mg} / \mathrm{l}$ in water under natural conditions (Cushing et al. 1973). The nitrate concentration varies from 0.4 to $6.0 \mathrm{mg} / \mathrm{l}$ with a mean value of $3.87 \mathrm{mg} / \mathrm{l}$. The concentration of nitrate is within the WHO-suggested permissible limit (45 mg/l). Ammonium is transferred to nitrate by the nitrification process in the presence of oxygen

$2 \mathrm{O}_{2}+\mathrm{NH}_{4}^{+}=\mathrm{NO}_{3}^{-}+\mathrm{H}_{2} \mathrm{O}$

The possible sources of nitrates are poultry farms, animal wastages and septic tank leakages in the urban area. Nitrate leaching is enhanced by high infiltration of soil layer and low runoff potential. The presence of high nitrate concentration in the drinking water increases the incidence of gastric cancer and other potential hazards to infants and pregnant women (Nagireddi Srinivasa Rao 2006).

The concentration of calcium and magnesium ranges from 30 to $200 \mathrm{mg} / \mathrm{l}$ and 1.2 to $164 \mathrm{mg} / \mathrm{l}$, respectively. The calcium and magnesium ions present in the groundwater are possibly derived from leaching of calcium and magnesium-bearing rock-forming silicates, limestone, dolomite, gypsum and anhydrides. The majority of groundwater shows concentration of calcium and magnesium above the WHO (2011) suggested maximum permissible limit.

The concentration of sodium and potassium varied from 69 to $1,490 \mathrm{mg} / \mathrm{l}$ and from 8 to $340 \mathrm{mg} / \mathrm{l}$, respectively. The high concentration of sodium ions among the cationic concentrations reflects rock weathering and/or dissolution of soil salts stored by the influence of evaporation (Stallard and Edmond 1983) and also indicates its higher solubility behaviour, whereas the high concentration of sodium and chloride suggest the seawater percolation in the coastal aquifers. The sodium and potassium concentrations exceeded the WHO standard in the majority of the samples. The lowest concentration of calcium compared to alkali elements is due to the ion exchange process, which indirectly indicates the dominancy of alkalis over alkali earth elements. Moreover, the excess of alkali earth elements $(\mathrm{Ca}+\mathrm{Mg})$ over $\mathrm{HCO}_{3}{ }^{-}$in the groundwater clearly indicates that they are supplied from silicate-weathering processes (Zhang et al. 1995). The dominance of major cations and anions are shown as follows: $\mathrm{Na}^{+}>\mathrm{K}^{+}>\mathrm{Ca}^{2+}$ $>\mathrm{Mg}^{2+}=\mathrm{Cl}^{-}>\mathrm{SO}_{4}{ }^{2-}>\mathrm{HCO}_{3}{ }^{-}>\mathrm{CO}_{3}{ }^{-}$.

Hydrogeochemical characteristics of groundwater

The piper diagram (Piper 1944) is an effective tool to evaluate the hydrogeochemical parameters of groundwater by plotting the concentration of major ions in the piper diagram. The diagram has two triangular fields and a diamond-shaped field. Different types of groundwater can be identified by their position in the diamond field. The cations expressed as percentage of total cations in meq/l as a single point on the left triangle, while anions are plotted on the right triangle. Each point is then projected into the upper field along a line parallel to the upper margin of the field and the point where the extension intersects indicates the character of the water as represented by the relationship among $\mathrm{Na}^{+}+\mathrm{K}^{+}, \mathrm{Ca}^{2+}+\mathrm{Mg}^{2+}, \mathrm{CO}_{3}{ }^{-}+\mathrm{HCO}_{3}{ }^{-}$and $\mathrm{Cl}^{-}+\mathrm{SO}_{4}{ }^{2-}$ ions. Similarities and differences among groundwater samples can be revealed from the trilinear plot because water of similar qualities will tend to plot together as groups. Distinct groundwater qualities can be quickly distinguished by their plotting in certain areas of the diamond field. The analytical value obtained from the groundwater is plotted on piper diagram to understand the hydrogeochemical regime of the study area. The diamondshaped fields of piper diagram are further divided into four classes, namely $\mathrm{Ca}^{2+}-\mathrm{Mg}^{2+}-\mathrm{Cl}^{-}-\mathrm{SO}_{4}{ }^{2-}, \mathrm{Na}^{+}-\mathrm{K}^{+}-\mathrm{Cl}^{-}-$ $\mathrm{SO}_{4}{ }^{2-}, \mathrm{Na}^{+}-\mathrm{K}^{+}-\mathrm{Cl}^{-}-\mathrm{HCO}_{3}{ }^{-}$and $\mathrm{Ca}^{2+}-\mathrm{Mg}^{2+}-\mathrm{HCO}_{3}{ }^{-}$. The dominant water types of the study area are in the order of mixed $\mathrm{Ca}-\mathrm{Mg}-\mathrm{Cl}>\mathrm{Na}-\mathrm{Cl}$ (Fig. 2). The diagram can evaluate the hydrochemistry of groundwater with the help of Aquachem 4.0 software. According to Appelo and Postma (1996), dominant water types like $\mathrm{Na}-\mathrm{Cl}$ and $\mathrm{Ca}-$ $\mathrm{Cl}$ indicate the seawater intrusion process. The majority of the sampling points clustered on the $\mathrm{Na}-\mathrm{Cl}$ and mixed $\mathrm{Ca}-$ $\mathrm{Mg}-\mathrm{Cl}$ facies suggesting that the mixing of high-salinity water was caused from seawater intrusion by overexploitation followed by domestic wastewater, septic tank waste infiltration and ionic exchange process. In the dominant facies, $\mathrm{Na}-\mathrm{Cl}$ type contributes to $91.3 \%$ of samples and the second most dominant facies, mixed $\mathrm{Ca}-\mathrm{Mg}-\mathrm{Cl}$ type, contributes to $86.9 \%$. This indicates that alkali $\left(\mathrm{Na}^{+}+\mathrm{K}^{+}\right)$ 
Fig. 2 Groundwater hydrogeochemical facies plot (piper plot) of the study area

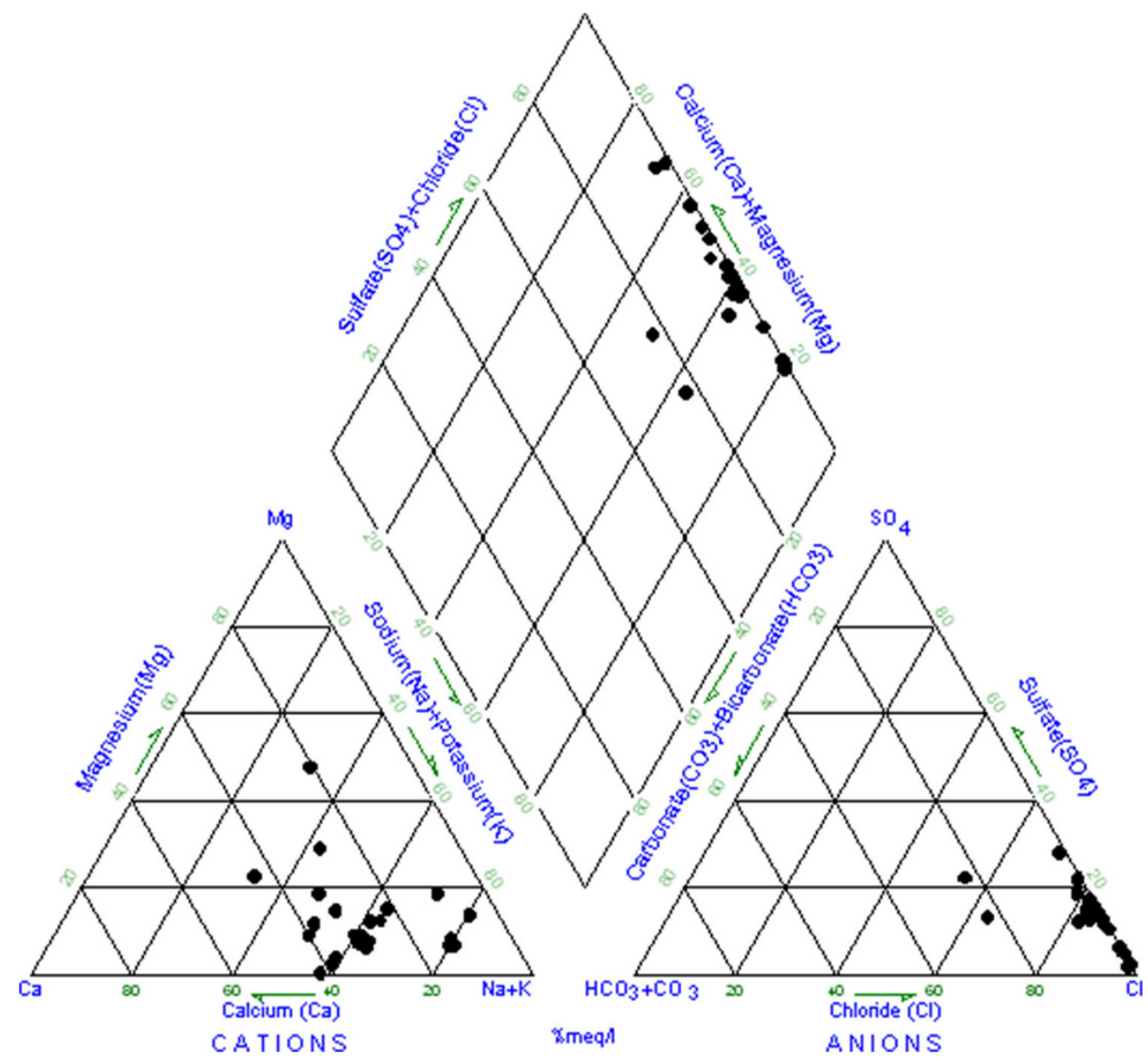

and strong acids $\left(\mathrm{Cl}^{-}+\mathrm{SO}_{4}{ }^{2-}\right)$ dominate over alkaline earth $\left(\mathrm{Ca}^{2+}+\mathrm{Mg}^{2+}\right)$ and weak acids. Elevated $\mathrm{Na}^{+}$concentrations coupled with low $\mathrm{Ca}^{2+}$ suggest that $\mathrm{Ca}^{2+}$ and $\mathrm{Na}^{+}$ion exchange process is an important geochemical process for the $\mathrm{Na}-\mathrm{Cl}$ type of groundwater.

Gibbs plot (Gibbs 1970) is used to interpret the effect of hydrogeochemical processes such as precipitation, rockwater interaction and evaporation on groundwater geochemistry. The reaction between groundwater and aquifer minerals has a significant role in water quality which is useful to understand the genesis of water. Gibbs ratio is calculated using the following equation (Eqs. 10, 11):

Gibbs ratio I (for anion) $=\frac{\mathrm{Cl}^{-}}{\left(\mathrm{Cl}^{-}+\mathrm{HCO}_{3}^{-}\right)}$

Gibbs ratio II (for cation) $=\frac{\mathrm{Na}^{+}+\mathrm{K}^{+}}{\left(\mathrm{Na}^{+}+\mathrm{K}^{+}+\mathrm{Ca}^{2+}\right)}$

The sampling points mostly fall in the rock-water interaction and evaporation zone (Fig. 3). The rock domain suggests that rock-water interaction is the major source of dissolved ions over the control of groundwater chemistry. The rock-water interaction process includes the chemical weathering of rocks, dissolution-precipitation of secondary carbonates and ion exchange between water and clay minerals. The moving of groundwater sampling points in the Gibbs field towards the evaporation domain from the rock domain suggests an increase of $\mathrm{Na}^{+}$and $\mathrm{Cl}^{-}$ions and consequent higher TDS due to water contamination, caused by the influences of seawater contamination and poor sanitary conditions.

The chloro-alkaline indices (CA) are widely used to assess the ion exchange reactions between groundwater and its host rock (Schoeller 1967). During ion exchange, $\mathrm{Ca}^{2+}$ and $\mathrm{Mg}^{2+}$ ions present in groundwater react with clay minerals to release $\mathrm{Na}^{+}$ions. $\mathrm{Na}^{+}$and $\mathrm{K}^{+}$ions in the water are exchanged with $\mathrm{Mg}^{2+}$ and $\mathrm{Ca}^{2+}$ ions, if the indices values are positive, which indicates base-exchange reaction, whereas negative values indicates chloro-alkaline disequilibrium. The reaction is known as cation exchange reaction. During this process, the host rocks are the primary sources of dissolved solids in the water. From the results, nearly $70 \%$ of samples show positive results with the baseexchange reaction between $\mathrm{Na}^{+}, \mathrm{K}^{+}, \mathrm{Mg}^{2+}$ and $\mathrm{Ca}^{2+}$ in groundwater. High base-exchange reaction in which alkali earth elements are exchanged for $\mathrm{Na}^{+}$ion $\left(\mathrm{HCO}_{3}{ }^{-}>\right.$ $\left.\mathrm{Ca}^{2+}+\mathrm{Mg}^{2+}\right)$ may be referred to as base-exchange softened water, whereas $\mathrm{Na}^{+}$ion is exchanged for the alkali 
Fig. 3 Gibbs diagram for the major cations and anions in the groundwater

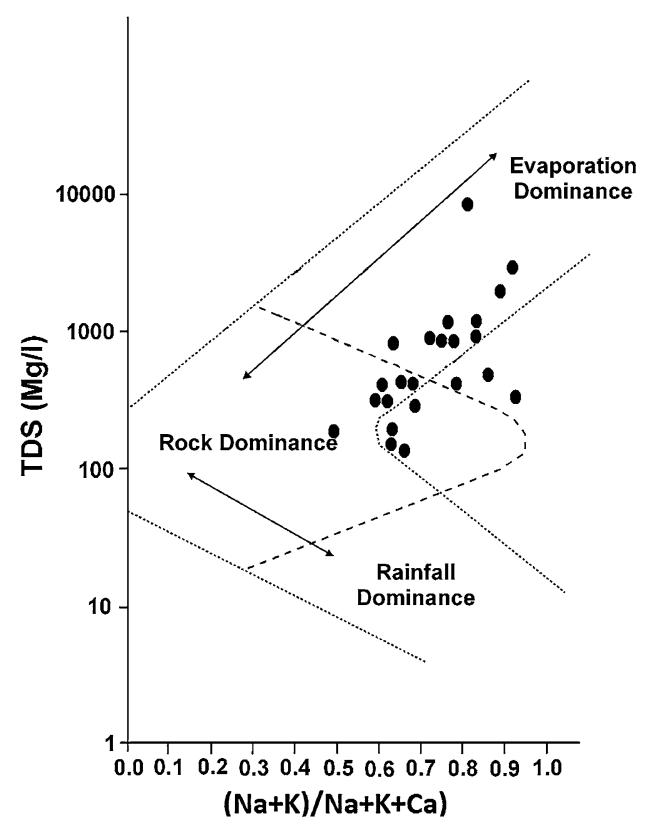

earths $\left(\mathrm{Ca}^{2+}+\mathrm{Mg}^{2+}>\mathrm{HCO}_{3}^{-}\right)$can be referred to as base-exchange hard water (Jeevanandam et al. 2012). In this study, most of the samples are base-exchange soft water in nature and few samples are converted to baseexchange hard water due to the precipitation process. The chloro-alkaline indices and the concentration of cations and anions in meq/l are computed using the following equations (Eqs. 12, 13).

Chloro - alkaline index $\mathrm{I}=\frac{\mathrm{Cl}^{-}-\mathrm{Na}^{+}+\mathrm{K}^{+}}{\mathrm{Cl}^{-}}$

Chloro - alkaline index II $=\frac{\mathrm{Cl}^{-}-\mathrm{Na}^{+}+\mathrm{K}^{+}}{\mathrm{SO}_{4}^{2-}+\mathrm{HCO}_{3}^{-}+\mathrm{CO}_{3}^{2-}+\mathrm{NO}_{3}^{-}}$

\section{Correlation matrix}

The chemical composition of the groundwater is characterized by major cations and anions such as $\mathrm{Ca}^{2+}, \mathrm{Mg}^{2+}$, $\mathrm{Na}^{+}, \mathrm{K}^{+}, \mathrm{Cl}^{-}, \mathrm{SO}_{4}{ }^{2-}, \mathrm{CO}_{3}{ }^{-}, \mathrm{HCO}_{3}{ }^{-}$and $\mathrm{NO}_{3}$. The correlation matrix of the physico-chemical parameters is shown in Table 2. The correlation matrix and R-mode factor analysis (principal component analysis) was carried out using SPSS software (1999). Principal components analysis (PCA) was useful for data reduction, to assess the continuity/overlap of clusters or clustering/similarities in the data and was used to determine the sources of variation between parameters (Guler et al. 2002). The extracted factor results suggest that $\mathrm{Cl}^{-}, \mathrm{SO}_{4}{ }^{2-}, \mathrm{Ca}^{2+}, \mathrm{Na}^{+}, \mathrm{K}^{+}, \mathrm{EC}$ and TDS have high positive factor loadings in factor 1 and $\mathrm{HCO}_{3}{ }^{-}$, TDS, EC, temperature and $\mathrm{NO}_{3}$ have high positive factor loadings in factor 2, whereas $\mathrm{HCO}_{3}, \mathrm{Mg}$ and $\mathrm{Na}$ have a high positive factor loading in factor 3 (Table 3). Three factor variables with different factor loadings explain the reason for the variation in geochemical composition of groundwater. A strong positive correlation between $\mathrm{Na}^{+}$ and $\mathrm{Cl}^{-}$suggests mixing of groundwater with two different compositions (fresh and saline) and a strong relationship with $\mathrm{SO}_{4}{ }^{2-}$ and $\mathrm{Cl}^{-}$may be related to the long history of evaporation. The strong relationship with high positive factor loading between $\mathrm{Ca}^{2+}$ and $\mathrm{SO}_{4}{ }^{2-}$ suggests the gypsum dissolution process. The positive loadings of $\mathrm{pH}$, EC and TDS suggest that they probably controlled the concentration of major ions in groundwater. The concentration of nitrate in the groundwater was significantly derived from anthropogenic processes.

Water quality classification

Water quality index

The water quality assessment indices (WQIs) are aggregation and communication tools for monitoring water quality (Vasanthavigar et al. 2010). These indices have been developed to summarize water quality data in an easily expressible and understandable format with less information than the raw data. WHO (World Health Organization 2011) standards, assigned weight $\left(w_{i}\right)$ and a relative weight $\left(W_{i}\right)$ for each parameter are listed in Table 4. The calculated WQI ranges from 45.59 to 622.09 . The classification ranges for the water quality index (WQI) are given in Table 5. Based on the groundwater quality index, $17.9 \%$ of the samples fall under excellent and unsuitable category, 34.8 and $21.7 \%$ fall under good and poor water category and $8.7 \%$ under very poor for drinking purpose category (Table 6).

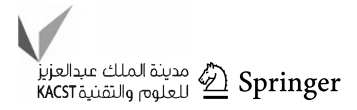


Table 2 Correlation coefficient matrix of major cations and anions of the study area

\begin{tabular}{|c|c|c|c|c|c|c|c|c|c|c|c|c|c|}
\hline Parameters & Temperature & $\mathrm{pH}$ & $\mathrm{EC}$ & TDS & $\mathrm{CO}_{3}$ & $\mathrm{HCO}_{3}$ & $\mathrm{Cl}$ & $\mathrm{SO}_{4}$ & $\mathrm{NO}_{3}$ & $\mathrm{Ca}$ & $\mathrm{Mg}$ & $\mathrm{Na}$ & $\mathrm{K}$ \\
\hline Temperature & 1.000 & & & & & & & & & & & & \\
\hline $\mathrm{pH}$ & -0.259 & 1.000 & & & & & & & & & & & \\
\hline $\mathrm{EC}$ & -0.013 & 0.041 & 1.000 & & & & & & & & & & \\
\hline TDS & -0.013 & 0.041 & 1.000 & 1.000 & & & & & & & & & \\
\hline $\mathrm{CO}_{3}$ & -0.015 & -0.130 & -0.109 & -0.109 & 1.000 & & & & & & & & \\
\hline $\mathrm{HCO}_{3}$ & 0.098 & -0.310 & 0.527 & 0.527 & -0.006 & 1.000 & & & & & & & \\
\hline $\mathrm{Cl}$ & -0.020 & 0.198 & 0.425 & 0.425 & 0.423 & -0.087 & 1.000 & & & & & & \\
\hline $\mathrm{SO}_{4}$ & 0.213 & 0.336 & 0.541 & 0.541 & 0.084 & 0.153 & 0.749 & 1.000 & & & & & \\
\hline $\mathrm{NO}_{3}$ & 0.327 & 0.125 & 0.254 & 0.254 & -0.124 & 0.320 & 0.129 & 0.618 & 1.000 & & & & \\
\hline $\mathrm{Ca}$ & 0.114 & 0.484 & 0.510 & 0.510 & -0.073 & -0.173 & 0.675 & 0.777 & 0.333 & 1.000 & & & \\
\hline $\mathrm{Mg}$ & 0.003 & 0.278 & 0.310 & 0.310 & 0.375 & -0.112 & 0.813 & 0.562 & 0.105 & 0.484 & 1.000 & & \\
\hline $\mathrm{Na}$ & -0.108 & 0.272 & 0.490 & 0.490 & 0.334 & -0.087 & 0.977 & 0.789 & 0.138 & 0.731 & 0.764 & 1.000 & \\
\hline $\mathrm{K}$ & 0.089 & 0.319 & 0.463 & 0.463 & 0.143 & -0.016 & 0.810 & 0.866 & 0.507 & 0.697 & 0.774 & 0.817 & 1.000 \\
\hline
\end{tabular}

Table 3 Factor analysis (R mode) of major cations and anions of the study area

\begin{tabular}{llcr}
\hline Parameters & 1 & 2 & 3 \\
\hline Temperature & $6.12 \mathrm{E}-02$ & 0.271 & -0.176 \\
$\mathrm{pH}$ & 0.348 & -0.357 & -0.579 \\
$\mathrm{EC}$ & 0.672 & 0.593 & 0.176 \\
$\mathrm{TDS}$ & 0.672 & 0.593 & 0.176 \\
$\mathrm{CO}_{3}$ & 0.181 & -0.406 & 0.67 \\
$\mathrm{HCO}_{3}$ & 0.1 & $\mathbf{0 . 8 1 8}$ & $\mathbf{0 . 3 4 2}$ \\
$\mathrm{Cl}$ & $\mathbf{0 . 8 8 6}$ & -0.313 & $\mathbf{0 . 2 5 9}$ \\
$\mathrm{SO}_{4}$ & $\mathbf{0 . 9 1 5}$ & $9.83 \mathrm{E}-02$ & -0.195 \\
$\mathrm{NO}_{3}$ & 0.424 & 0.419 & -0.436 \\
$\mathrm{Ca}$ & $\mathbf{0 . 8 2 4}$ & $-7.69 \mathrm{E}-02$ & -0.352 \\
$\mathrm{Mg}$ & 0.761 & -0.366 & 0.218 \\
$\mathrm{Na}$ & $\mathbf{0 . 9 1 2}$ & -0.275 & 0.187 \\
$\mathrm{~K}$ & $\mathbf{0 . 9 1 6}$ & -0.104 & -0.101 \\
\hline
\end{tabular}

\section{Fuzzy membership functions}

Water quality management is characterized by imprecision in objective and water quality standards. Fuzzy logic is a mathematical tool that converts complicated statements into mathematical terms and again converts them into simple outputs. The output vector data are based on some set of rules and assigned values for output data. The rules are developed and utilized by fuzzy interference to derive output from input database. Fuzzy set theory and its derivatives may be used to directly introduce imprecise data into mathematical models with minimum input data requirements (Ferson et al. 1994). Fuzzy membership classification of drinking water quality was calculated according to the quality standards (Table 7). The distinguished fuzzy classifications based on fuzzy scores are
Table 4 Relative weight of physico-chemical parameters and WHO water quality standards

\begin{tabular}{llll}
\hline $\begin{array}{l}\text { Chemical } \\
\text { parameters }\end{array}$ & $\begin{array}{l}\text { WHO } \\
\text { standards } \\
(2004)\end{array}$ & $\begin{array}{l}\text { Weight } \\
\left(w_{i}\right)\end{array}$ & $\begin{array}{l}\text { Relative weight } \\
W_{i}=w_{i} / \sum_{i=1}^{n} w_{i}\end{array}$ \\
\hline $\mathrm{pH}($ on scale) & $6.5-8.5$ & 4 & 0.114 \\
$\mathrm{EC}(\mu \mathrm{S} / \mathrm{cm})$ & 500 & 4 & 0.114 \\
$\mathrm{TDS}(\mathrm{mg} / \mathrm{l})$ & 500 & 5 & 0.142 \\
$\mathrm{HCO}_{3}(\mathrm{mg} / \mathrm{l})$ & 500 & 3 & 0.086 \\
$\mathrm{Cl}(\mathrm{mg} / \mathrm{l})$ & 250 & 3 & 0.086 \\
$\mathrm{SO}_{4}(\mathrm{mg} / \mathrm{l})$ & 250 & 4 & 0.114 \\
$\mathrm{NO}_{3}(\mathrm{mg} / \mathrm{l})$ & 45 & 5 & 0.142 \\
$\mathrm{Ca}(\mathrm{mg} / \mathrm{l})$ & 75 & 2 & 0.057 \\
$\mathrm{Mg}(\mathrm{mg} / \mathrm{l})$ & 50 & 1 & 0.029 \\
$\mathrm{Na}(\mathrm{mg} / \mathrm{l})$ & 200 & 2 & 0.057 \\
$\mathrm{~K}(\mathrm{mg} / \mathrm{l})$ & 200 & 2 & 0.057 \\
& & $\sum w_{i}=35$ & $\sum w_{i}=0.998$ \\
\hline
\end{tabular}

$<50$ - excellent water; 50 to 100 - good water; 100 to 200 - poor water; 200 to 300 - very poor water and $>300$ - unfit for drinking water. The calculated fuzzy logic scores of the study area indicate that $17.4 \%$ of the samples fall under fuzzy class I, $34.8 \%$ under class II, $21.7 \%$ under class III, and 8.69 and $17.4 \%$ under class IV and V, respectively.

\section{Conclusion}

In the present study, 23 groundwater samples were collected, analysed and assessed for drinking water quality. The $\mathrm{pH}$ value of the groundwater was slightly acidic to basic in nature. Based on EC classification, the groundwater sample is falling under fresh to brackish in nature. 
Table 5 Water quality classification ranges and types of water based on WQI values

\begin{tabular}{ll}
\hline Range & Type of water \\
\hline$<50$ & Excellent water \\
$50-100.1$ & Good water \\
$100-200.1$ & Poor water \\
$200-300.1$ & Very poor water \\
$>300$ & Water unsuitable for drinking purposes \\
\hline
\end{tabular}

Table 6 Water quality index (WQI) classification for individual samples

\begin{tabular}{lll}
\hline S. No & WQI values & Classification type \\
\hline 1 & 524.4051542 & Water unsuitable for drinking purposes \\
2 & 263.4938237 & Very poor water \\
3 & 133.7036312 & Poor water \\
4 & 45.59138672 & Excellent water \\
5 & 65.8518405 & Good water \\
6 & 51.22746881 & Good water \\
7 & 45.61542152 & Excellent water \\
8 & 51.68121237 & Good water \\
9 & 135.5442537 & Poor water \\
10 & 47.90465095 & Excellent water \\
11 & 303.9329226 & Water unsuitable for drinking purposes \\
12 & 105.0309461 & Poor water \\
13 & 104.4600438 & Poor water \\
14 & 622.0980452 & Water unsuitable for drinking purposes \\
15 & 139.8106837 & Poor water \\
16 & 493.2826235 & Water unsuitable for drinking purposes \\
17 & 273.0413338 & Very poor water \\
18 & 81.10454421 & Good water \\
19 & 78.27814748 & Good water \\
20 & 73.53216787 & Good water \\
21 & 83.29448308 & Good water \\
22 & 46.82966528 & Excellent water \\
23 & 77.20414463 & Good water \\
\hline & & \\
\hline 19 & & \\
12 & &
\end{tabular}

The aquifers are contaminated with sodium, chloride, sulphate and nitrate, which may cause serious health hazards to the populated areas of the study area. The quality of the groundwater in the study area is impaired by seawater intrusion and rock-water interaction processes. According to piper diagram, the dominant salt combinations of the groundwater in the study area are $\mathrm{Na}-\mathrm{Cl}$ and mixed $\mathrm{Ca}-$ $\mathrm{Mg}-\mathrm{Cl}$. Fuzzy membership classification and WQI values suggest that the majority of the samples fall under excellent and poor water quality classes. Groundwater sustainability for drinking usage was evaluated by WHO and BIS standards. Based on the standards, around $60.8 \%$ of the samples are suitable for drinking purposes. Geochemical
Table 7 Water quality class assessment by fuzzy membership function

\begin{tabular}{llllllll}
\hline Water samples & \multicolumn{4}{c}{ Number of sample within class } & \multirow{2}{*}{ Total } \\
\cline { 2 - 6 } & I & II & III & IV & V & \\
\hline Groundwater & 4 & 8 & 5 & 2 & 4 & 23
\end{tabular}

parameters such as $\mathrm{Cl}^{-}, \mathrm{SO}_{4}{ }^{2-}, \mathrm{Ca}^{2+}, \mathrm{Na}^{+}, \mathrm{K}^{+}$and $\mathrm{NO}_{3}$ show good correlation with positive factor loadings. The groundwater aquifers of the study area are contaminated by seawater intrusion, gypsum dissolution and waste water disposal by urban and industrial activities. Based on the hydrogeochemical investigations, WHO and BIS standards, the groundwater samples can be used for drinking after removing and reducing the concentration of $\mathrm{Cl}^{-}, \mathrm{SO}_{4}{ }^{2-}$, $\mathrm{Ca}^{2+}, \mathrm{Na}^{+}$and $\mathrm{K}^{+}$in groundwater.

Acknowledgments KK thanks Dr. V. B. M. Sayana, Professor and Head, Department of Civil Engineering, St. Peters University and Prof. P. Partheeban, Dean Academic, St. Peters College of Engineering and Technology, Avadi, Chennai, for their moral support and providing permission to publish this student project work (Project No: SPU/CE/A10/2011-12).

Open Access This article is distributed under the terms of the Creative Commons Attribution License which permits any use, distribution, and reproduction in any medium, provided the original author(s) and the source are credited.

\section{References}

APHA (1995) Standard methods for the examination of water and wastewater, 19th edn. American Public Health Association, Washington, DC, pp 1-467

Appelo C, Postma D (1996) Geochemistry, groundwater and pollution. Balkema, Rotterdam

Arunprakash M, Giridharan L, Krishnamurthy RR, Jayaprakash M (2013) Impact of urbanization in groundwater of south Chennai City, Tamil Nadu, India. Environ Earth Sci. doi 10.1007/s12665013-2496-7

Ballukraya PN, Ravi R (1998) Natural fresh water ridge as barrier against sea water intrusion in Chennai city. J Geol Soc India 52(3):279-286

Baruah M, Bhattacharyya KG, Patgiri AD (2008) Water quality of shallow groundwater of core city area of Guwahati. In: Proceedings of sixteenth national symposium on environment, Haryana, India, pp 101-106

BIS (Breau of Indian Standards) 10500 (1991) Indian Standard drinking water specification (1st rev.) pp 1-8)

Chidambaram S, Prasanna MV, Vasu K, Shahul Hameed A, Unnikrihna Warrier C, Srinivasamoorthy K, John Peter A, Anandhan P (2007) Study on the stable isotope signatures in groundwater of Gudilum River Basin, Tamil Nadu. Ind J Geochem 22(2):209-221

Cushing EM, Kantrowitz IH, Taylor KR (1973) Water resources of the Delmarva Peninsular. U S Geological Survey Professional Paper 822, Washington DC 
Ferson S, Millstein J, Mauriello D (1994) Environmental risk assessment using interval analysis and fuzzy arithmetic. Association with 1994 annual meeting of the Society for Risk Analysis, Boltimore

Gibbs RJ (1970) Mechanisms controlling world water chemistry. Sci J 170:795-840

Guler C, Thyne GD, McCray JE, Turner AK (2002) Evaluation of graphical and multivariate statistical methods for classification of water chemistry data. Hydrogeol J 10(4):455-474

Jeevanandam M, Nagarajan R, Manikandan M, Senthilkumar M, Srinivasalu S, Prasanna MV (2012) Hydrogeochemistry and microbial contamination of groundwater from Lower Ponnaiyar Basin, Cuddalore District, Tamil Nadu, India. Environ Earth Sci 67(3):867-887

Jeong CH (2001) Effects of land use and urbanization on hydrochemistry and contamination of groundwater from Taejon area, Korea. J Hydrol 253:194-210

KrishnaKumar S, Chandrasekar N, Seralathan P, Godson PS, Magesh NS (2011) Hydrogeochemical study of shallow carbonate aquifers, Rameswaram Island, India. Environ Monit Assess 184(7):4127-4139

Magesh NS, Krishnakumar S, Chandrasekar N, Soundranayagam JP (2012) Groundwater quality assessment using WQI and GIS techniques, Dindigul district, Tamil Nadu, India. Arab J Geosci 6(11):4179-4189

Nagireddi Srinivasa Rao (2006) Nitrate pollution and its distribution in the groundwater of Srikakulam district, Andhra Pradesh, India. Environ Geol 51(4):631-645

Piper AM (1944) A graphical interpretation of water analysis. Trans AGU 25:914-928

Sarath Prasanth SV, Magesh NS, Jitheshlal KV, Chandrasekar N, Gangadhar K (2012) Evaluation of groundwater quality and its suitability for drinking and agricultural use in the coastal stretch of Alappuzha District, Kerala, India. Appl Water Sci 2(3):165-175

Schoeller H (1967) Geochemistry of groundwater. An international guide for research and practice UNESCO, chap 15, pp 1-18
SPSS Inc (1999) SPSS for Windows, Rel. 10.0.1. SPSS Inc., Chicago Stallard RE, Edmond JM (1983) Geochemistry of Amazon River: the influence of the geology and weathering environment on the dissolved load. J Geophys Res 88:9671-9688

Todd DK (1980) Groundwater hydrology. Wiley, New York

Vasanthavigar M, Srinivasamoorthy K, Vijayaragavan K, Rajiv Ganthi R, Chidambaram S, Anandhan P, Manivannan R, Vasudevan S (2010) Application of water quality for groundwater quality assessment: thirumanimuttar Sub basin, Tamil Nadu, India. Environ Monit Assess 171(1-4):595-609

Venugopal T, Giridharan L, Jayaprakash M (2009) Environmental impact assessment and seasonal variation study of the groundwater in the vicinity of River Adyar, Chennai, India. Environ Monit Assess 149(1-4):81-97

Vodela JK, Renden JA, Lenz SD, McElhenney WH, Kemppainen BW (1997) Drinking water contaminants (arsenic, cadmium, lead, benzene and trichloroethylene). 1. Interaction of contaminants with nutritional status on general performance and immune function in broiler chickens. Poult Sci 76:1474-1492

Walker GR, Jolly ID, Cook PG (1991) A new chloride leaching approach to the estimation of diffuse recharge following a change in land use. J Hydrol 128:49-67

Whittemore DO, Greggor KMM, Marotz GA (1989) Effects of variations in recharge on groundwater quality. J Hydrol 106:131-145

WHO (2011) Guidelines for drinking-water quality, 4th edn. World Health Organization, Geneva

Zhang J, Huang WW, Letolle R, Jusserand C (1995) Major element chemistry of the Huanghe (Yellow River), China: weathering processes and chemical fluxes. J Hydrol 168:173-203

Zhang Bing, Song Xianfang, Zhang Yinghua, Han Dongmei, Tang Changyuan, Yilei Yu, Ma Ying (2012) Hydrochemical characteristics and water quality assessment of surface water and groundwater in Songnen Plain, Northeast China. Water Res $46: 2737-2748$ 